\title{
Studies on Testosterone Metabolism in
}

\section{Subjects with Testicular Feminization Syndrome}

\author{
P. Mauvais-Jarvis, J. P. Bercovici, O. Crepy, and F. Gauthier \\ From the Laboratoire de Chimie Biologique, C.H.U. La Pitié, Paris 13, France
}

A B S T RACT The metabolism of radioactive testosterone simultaneously administered intravenously and either orally or percutaneously has been studied in seven patients with the syndrome of testicular feminization and compared with that of normal males and females. This investigation was carried out in order to determine the relative contribution to urinary 17 -oxo and $17 \beta$ hydroxy androstane steroids of labeled testosterone, according to its mode of administration. In normal males the yields of urinary $5 \alpha$-androstane- $3 \alpha, 17 \beta$-diol (androstanediol) originating from either an intravenous or a percutaneous dose of testosterone were respectively 3 and 6 times higher than those arising from an oral dose which perfuses the liver directly. These data indicate that in normal males, testosterone might be $5 \alpha$-hydrogenated outside the liver. By contrast in patient with feminizing testes, because the contribution to androstanediol of radioactive testosterone is identical whatever its mode of administration, the extrahepatic $5 \alpha$-reduction of this substrate seems very unlikely.

The metabolic abnormalities observed in patients with testicular feminization syndrome may be reproduced in normal males by estrogen treatment. Nevertheless, the sensitivity of the patients to estrogen seems to be 10 times greater than that of normal males. This sensitivity was appreciated from the reduction of radioactive testosterone intravenously injected to urinary $17 \beta$-hydroxy-5 $\alpha$-androstan-3-one and androstanediol and also from the level of plasma binding for testosterone. This level was significantly higher $(P<0.05)$ in patients with feminizing testes than in normal males. The level increased dramatically after administration of a low dose of estrogen whereas this effect was not observed in normal males under the same experimental conditions.

In light of these results the defect of extrahepatic $5 \alpha$ reduction of testosterone observed in patients with

Part of this work has been published as a preliminary communication (14).

Received for publication 9 May 1969 and in revised form 22 August 1969. feminizing testes does not necessarily reflect an enzymatic impairment but might be related to an abnormal synthesis of plasma binding protein(s) under the effect of circulating estrogens so that an abnormally small amount of unbound testosterone may be available in target cells for $5 \alpha$-reduction.

\section{INTRODUCTION}

It is well known that the syndrome of testicular feminization develops in the presence of blood testosterone ${ }^{2}$ levels sufficiently to cause virilization in normal individuals (1-3). This observation suggests that the clinical manifestations of the syndrome are related to a defect in androgen action. Recently, we have reported that male sex differentiation is partly associated with a stimulation of enzymes allowing the ring $A$ reduction of testosterone to $17 \beta$-hydroxyandrostane steroids (Fig. 1) $(4,5)$. When normal males and hirsute females are intravenously injected with radioactive testosterone, the contribution of this precursor to urinary $5 \alpha$ - and $5 \beta$-androstane-3 $\alpha, 17 \beta$-diol is higher than in normal females and hypogonadal males with gonadotrophin deficiency. The treatment of the latter patients by chorionic gonadotrophin restores a normal male metabolic pattern. On the contrary, the administration of synthetic estrogens to normal males decreases the excretion of urinary metabolites originating from the ring A reduction of testosterone (6). In all these situations the yield of urinary $17 \beta$-hydroxyandrostane steroids arising from testosterone is correlated with the concentration of this an-

\footnotetext{
${ }^{1}$ The following trivial names have been used: $T=$ testosterone ; androstanolone $=17 \beta$-hydroxy-5 $\alpha$-androstan-3-one ; androstenedione $=$ androsta-4-ene-3,17-dione; androstanedione $=5 \alpha$-androstane-3,17-dione; androsterone $(\mathrm{A})=3 \alpha$-hydroxy-5 $\alpha$-androstan-17-one; isoandrosterone $=3 \beta$-hydroxy$5 \alpha$-androstan-17-one; $5 \beta$-androsterone $(5 \beta-A)=3 \alpha$-hydroxy$5 \beta$-androstan-17-one; androstanediol (Adiol) $=5 \alpha$-androstane-3 $\alpha, 17 \beta$-diol; $5 \beta$-androstanediol $(5 \beta$-Adiol $)=5 \beta$-androstane-3 $\alpha, 17 \beta$-diol; androstanediols $=$ diols $=$ androstanediol $+5 \beta$-androstanediol.
} 
drogen in biological fluids. This is not the case in patients with testicular feminization syndrome in whom, despite normal male testosterone secretion, the conversion of testosterone to androstanediols occurs at a very low rate $(5,7)$.

These clinical data are ascertained by the fact that labeled testosterone is not only taken up by accessory sex tissues but is also quickly metabolized in these tissues, particularly to $17 \beta$-hydroxy- $5 \alpha$-androstane metabolites $(8,9)$ which are known to be very potent androgens $(10,11)$. More recently, it has been reported that $17 \beta$-hydroxy-5 $\alpha$-androstan-3-one (androstanolone) is the only metabolite present in the prostatic nuclei after intravenous administration of radiocative testosterone to rats or after incubation of rat prostate with the same precursor $(12,13)$. The presence of a highly tissuespecific receptor for androstanolone in the prostatic nuclear chromatin indicates that this hydrogenated metabolite of testosterone might be an active form of androgen in the prostatic nuclei.

Therefore, it was very important to determine whether the small conversion of circulating testosterone to urinary androstanediols observed in patients with testicular feminization syndrome reflects an enzymatic impairment at the level of extrahepatic tissues. In this investigation data are presented which suggest that $5 \alpha$ hydrogenation of testosterone occurs in the target tis-

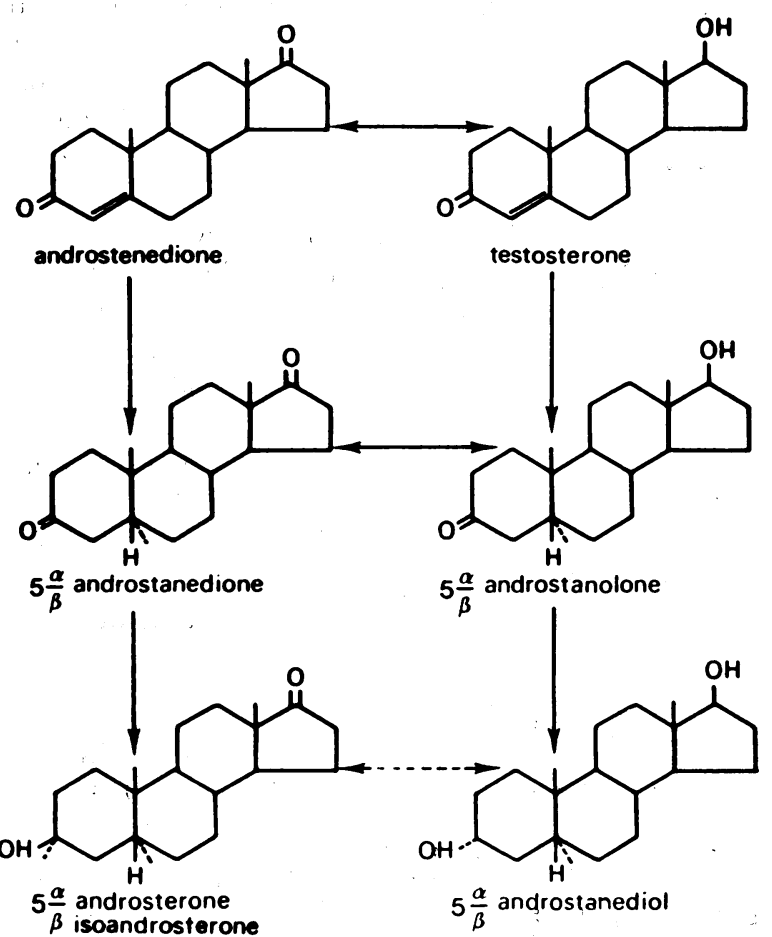

FIGURE 1 Different pathways of testosterone metabolism. sues of normal males and not in those of subjects with feminizing testes.

\section{METHODS}

Eight patients with testicular feminization syndrome were investigated. There were seven postpubertal untreated cases with the complete form of the syndrome. The symptoms are no axillary or pubic hair, no clitoris enlargement, and an XY karyotype. In addition a prepuberal $8 \mathrm{yr}$ old subject (case M. B.) was studied.

In six cases (five postpubertal cases and the prepuberal case), $1.0 \mu \mathrm{c}$ of testosterone $-4{ }^{14} \mathrm{C}$ (The Radiochemical Centre, Amersham, specific activity (SA) $29.2 \mathrm{mc} / \mathrm{mmole}$ ) was intravenously injected, and simultaneously, $10-12 \mu \mathrm{c}$ of testosterone-1,2- ${ }^{3} \mathrm{H}$ (Amersham, SA $1000 \mathrm{mc} / \mathrm{mmole}$ ) were orally administered. In the prepuberal case a combined ora and intravenous dose of testosterone was also given after treatment with $1 \mathrm{mg}$ of diethylstilbestrol daily for 10 days. The urine was collected for 3 days after the administration of labeled steroids. In three patients, $1.0 \mu \mathrm{c}$ of testosterone${ }^{14} \mathrm{C}$ was injected, and simultaneously, $23-30 \mu \mathrm{c}$ of testosterone ${ }^{3} \mathrm{H}$ dissolved in $100 \%$ ethanol were rubbed into the skin as previously reported (14). The urine was collected over 3 days after the administration of tracers. All these experiments were done under the same experimental conditions in normal males and females. In a postpubertal case (J. Q.) an intravenous dose of testosterone $-{ }^{14} \mathrm{C}$ was injected before and after castration. The first month was without hormonal treatment. After that, there was a daily injection of $25 \mathrm{mg}$ of testosterone propionate for 30 days and then an oral administration of $5 \mathrm{mg}$ of diethylstilbestrol for 20 days.

In addition, $0.5 \mu \mathrm{c}$ of testosterone $-{ }^{14} \mathrm{C}$ and $3.0-4.6 \mu \mathrm{c}$ of testosterone-17 $\alpha-{ }^{3} \mathrm{H}$, synthesized in the laboratory as previously described (15), were injected into one patient with testicular feminization syndrome and into one normal volunteer male before and after treatment with $50 \mathrm{mg}$ of diethylstilbestrol daily for 20 days. Another patient with testicular feminization and the same normal male were injected, under the same experimental conditions, with $1.0 \mu \mathrm{c}$ of testosterone- ${ }^{14} \mathrm{C}$ and $10-11 \mu \mathrm{c}$ of $17 \beta$-hydroxy-5 $\alpha$-androstan-3-one- ${ }^{8} \mathrm{H}$ (androstanolone) made in the laboratory according to the previously described procedure (16).

The recovery of radioactivity from aliquots of urine collections as androsterone (sulfate + glucuronide), $5 \beta$-androsterone (sulfate + glucuronide), androstanediol, and $5 \beta$-androstanediol (glucuronides) was measured. Details of the analysis procedure are as previously described $(5,15)$. The ${ }^{3} \mathrm{H}:{ }^{14} \mathrm{C}$ ratio of each urinary metabolite was constant throughout gradient elution, paper and thin-layer chromatography, and crystallization. After injection of testosterone${ }^{14} \mathrm{C}$ and androstanolone $-{ }^{8} \mathrm{H},{ }^{8} \mathrm{H}:{ }^{14} \mathrm{C}$ androstanolone was recovered in the urine as a ketonic glucuroconjugated steroid. As previously published (16), this metabolite was isolated in the radioactive isoandrosterone fraction after gradient-elution chromatography. It was further purified by paper chromatography (ligroin-propanediol system) and thin-layer chromatography (ethyl acetate:benzene, 1:1) which separated completely isoandrosterone, $5 \alpha$ - and $5 \beta$-androstanolone. The final product was crystallized in two different systems of solvents. Its radiochemical homogeneity was confirmed by a constant ${ }^{8} \mathrm{H}:{ }^{14} \mathrm{C}$ ratio and specific activity in crystals and mothers' liquors.

The relative binding affinity of serum protein for testosterone was determined by the semimicro method of Pearlman and Crepy (17). This technique is based on the principle of equilibrium dialysis with use of Sephadex G-25 (Pharmacia) 
in a batchwise fashion. With such a technique, it is possible under precise experimental conditions to determine the amount of serum proteins necessary to obtain $50 \%$ of binding with a given and very low concentration of radioactive steroid $\left(1 \times 10^{-6} \mathrm{~mole}\right)$. The relative binding activity may be expressed as $\mathrm{Sb} /(\mathrm{Su} \times \mathrm{P}), \mathrm{Sb}$ and $\mathrm{Su}$ representing respectively the bound and unbound steroid concentration and $P$, the amount of protein.

When $\mathrm{Sb} / \mathrm{Su}=1.0$, the binding affinity is equal to $1 / \mathrm{P}$. Expressed in liters per gram, this value is a good index of the relative binding affinity of testosterone for various sera.

This determination was performed in six cases of testicular feminization, five normal males, and eight females. In addition, this was repeated in four patients with feminizing testes and two volunteer normal males after administration of $5 \mathrm{mg}$ of diethylstilbestrol daily for 20 days.

\section{RESULTS}

Simultaneous administration of testosterone-' $H$ orally and testosterone ${ }^{-1} \mathrm{C}$ intravenously (Table I, Fig. 2). In normal males, females, or patients with feminizing testes, the recoveries of urinary $5 \beta$-androsterone originating from radioactive testosterone either orally or intravenously administered were not significantly different $(P<0.50$ for the three groups of subjects). Similarly in males, the per cent conversions of the two doses of testosterone to $5 \beta$-androstanediol did not differ significantly $(P<0.10)$. However in females, there was less $5 \beta$-androstanediol recovered in urine from the intravenously injected testosterone $(1.55 \pm 0.15 \% \mathrm{SE})$ than from the orally administered compound $(1.88 \pm 0.22 \%$ $\mathrm{SE})$. These values are significantly different $(P<0.05)$. In the case of patients with feminizing testes, the difference was more significant $(P<0.01)$ since $5 \beta$-androstanediol arising from intravenous testosterone (1.29 $\pm 0.42 \% \mathrm{SE}$ ) was half that arising from testosterone orally administered $(2.23 \pm 0.43 \% \mathrm{SE})$. These differ-

TABLE I

Recovery of Radioactivity in Urine after Simultaneous Administration of Radioactive Testosterone Intravenously $\left(T-{ }^{14} \mathrm{C}\right.$ i.v.) and Orally ( $T-{ }^{3} \mathrm{H}$ Oral $)$

\begin{tabular}{|c|c|c|c|c|c|c|c|c|c|}
\hline \multirow[b]{3}{*}{ Subjects } & \multirow[b]{3}{*}{ Age } & \multicolumn{8}{|c|}{ Per cent conversion of administered steroids } \\
\hline & & \multicolumn{2}{|c|}{$5 \boldsymbol{\beta}$-Androsterone } & \multicolumn{2}{|c|}{ Androsterone } & \multicolumn{2}{|c|}{$5 \beta$-Androstanediol } & \multicolumn{2}{|c|}{ Androstanediol } \\
\hline & & T-14C i.v. & T-s $\mathrm{H}$ oral & T-14C i.v. & $\mathrm{T}-\mathbf{2} \mathrm{H}$ oral & T-14C i.v. & T-2 $\mathrm{H}$ oral & T-14C i.v. & $\mathrm{T}-\mathbf{2} \mathrm{H}$ oral \\
\hline & $y r$ & & & & & & & & \\
\hline \multicolumn{10}{|c|}{ Testicular feminization } \\
\hline J. Q. & 30 & 15.5 & 16.3 & 23.6 & 19.7 & 1.22 & 2.31 & 0.50 & 0.35 \\
\hline N. V. & 20 & 11.1 & 10.6 & 20.0 & 19.0 & 1.11 & 2.23 & 0.44 & 0.38 \\
\hline F. L. & 21 & 9.9 & 11.6 & 20.1 & 16.7 & 1.47 & 3.01 & 0.57 & 0.34 \\
\hline A. G. & 19 & 21.8 & 21.7 & 16.2 & 15.4 & 1.44 & 1.80 & 0.59 & 0.42 \\
\hline G. P. & 20 & 11.7 & 11.4 & 20.0 & 15.2 & 1.23 & 1.81 & 0.39 & 0.25 \\
\hline Mean* & & 14.0 & 14.3 & 20.0 & 17.2 & 1.29 & 2.23 & 0.50 & 0.35 \\
\hline $\pm S E$ & & \pm 4.2 & \pm 3.7 & \pm 2.0 & \pm 1.8 & \pm 0.13 & \pm 0.42 & \pm 0.15 & \pm 0.06 \\
\hline M. B.f & 8 & & & & & & & 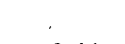 & \\
\hline Control & & 14.2 & 14.9 & 15.2 & 12.7 & 2.01 & 2.00 & 2.41 & 0.77 \\
\hline DES $\S$ & & 12.4 & 13.8 & 16.8 & 15.3 & 1.05 & 2.05 & 0.52 & 0.34 \\
\hline \multicolumn{10}{|c|}{ Normal males } \\
\hline A. $\mathrm{H}$. & 25 & 16.4 & 16.1 & 14.4 & 12.8 & 3.00 & 2.61 & 1.68 & 0.72 \\
\hline P. M. & 30 & 11.4 & 11.4 & 13.7 & 11.9 & 3.98 & 3.62 & 1.77 & 0.74 \\
\hline F. D. & 20 & 10.1 & 9.6 & 13.9 & 11.5 & 3.22 & 2.73 & 1.62 & 0.65 \\
\hline D. T. & 21 & 13.1 & 12.9 & 12.4 & 11.2 & 3.04 & 2.84 & 1.36 & 0.62 \\
\hline Mean & & 12.7 & 12.5 & 13.6 & 11.8 & 3.31 & 2.95 & 1.60 & 0.68 \\
\hline$\pm \mathrm{SE}$ & & \pm 2.6 & \pm 2.3 & \pm 0.7 & \pm 0.6 & \pm 0.44 & \pm 0.44 & \pm 0.20 & \pm 0.17 \\
\hline \multicolumn{10}{|c|}{ Normal females } \\
\hline N. J. & 21 & 12.1 & 11.3 & 8.4 & 8.8 & 1.63 & 1.82 & 0.59 & 0.32 \\
\hline M. C. & 20 & 13.4 & 12.1 & 9.5 & 9.5 & 1.65 & 2.21 & 0.69 & 0.41 \\
\hline J. R. & 23 & 11.9 & 11.3 & 8.7 & 8.2 & 1.38 & 1.63 & 0.59 & 0.35 \\
\hline Mean & & 12.4 & 11.5 & 8.7 & 8.8 & 1.55 & 1.88 & 0.62 & 0.36 \\
\hline$\pm \mathrm{SE}$ & & \pm 0.9 & \pm 0.5 & \pm 0.5 & \pm 0.7 & \pm 0.15 & \pm 0.22 & \pm 0.06 & \pm 0.05 \\
\hline
\end{tabular}

* Patients with the complete form of the syndrome after puberty and before castration.

$\ddagger$ Prepuberal case.

$\S$ After treatment with $1 \mathrm{mg}$ of diethylstilbestrol daily $\times 10$ days. 
ences may also be expressed by calculating the proportion of the intravenous compared with the oral dose of radioactive testosterone excreted as $5 \beta$-androstanediol, i.e., the $R$ value of $5 \beta$-androstanediol. In the present experiments, this $R$ value was calculated by dividing the ${ }^{8} \mathrm{H}:{ }^{14} \mathrm{C}$ ratio of the injected steroids by the ${ }^{8} \mathrm{H}:{ }^{14} \mathrm{C}$ ratio in a purified sample of a metabolite. The mean $R$ values for $5 \beta$-androstanediol were 1.15 in males, 0.80 in females, and 0.60 in patients with feminizing testes. The three groups differ from one another $(P<0.01)$.
As regards androstanediol, the per cent conversion of the intravenously injected dose of testosterone was $1.60 \pm 0.20 \% \mathrm{SE}$ in males. This value was significantly higher $(P<0.05)$ than the per cent conversion of the oral dose of testosterone to the same metabolite $(0.68$ $\pm 0.17 \% \mathrm{SE}$ ). In females the difference was less important but still significant $(P<0.05)$. In patients with feminizing testes the yields of urinary androstanediol originating from either the intravenously or the orally administered testosterone were respectively $0.50 \pm 0.15 \%$

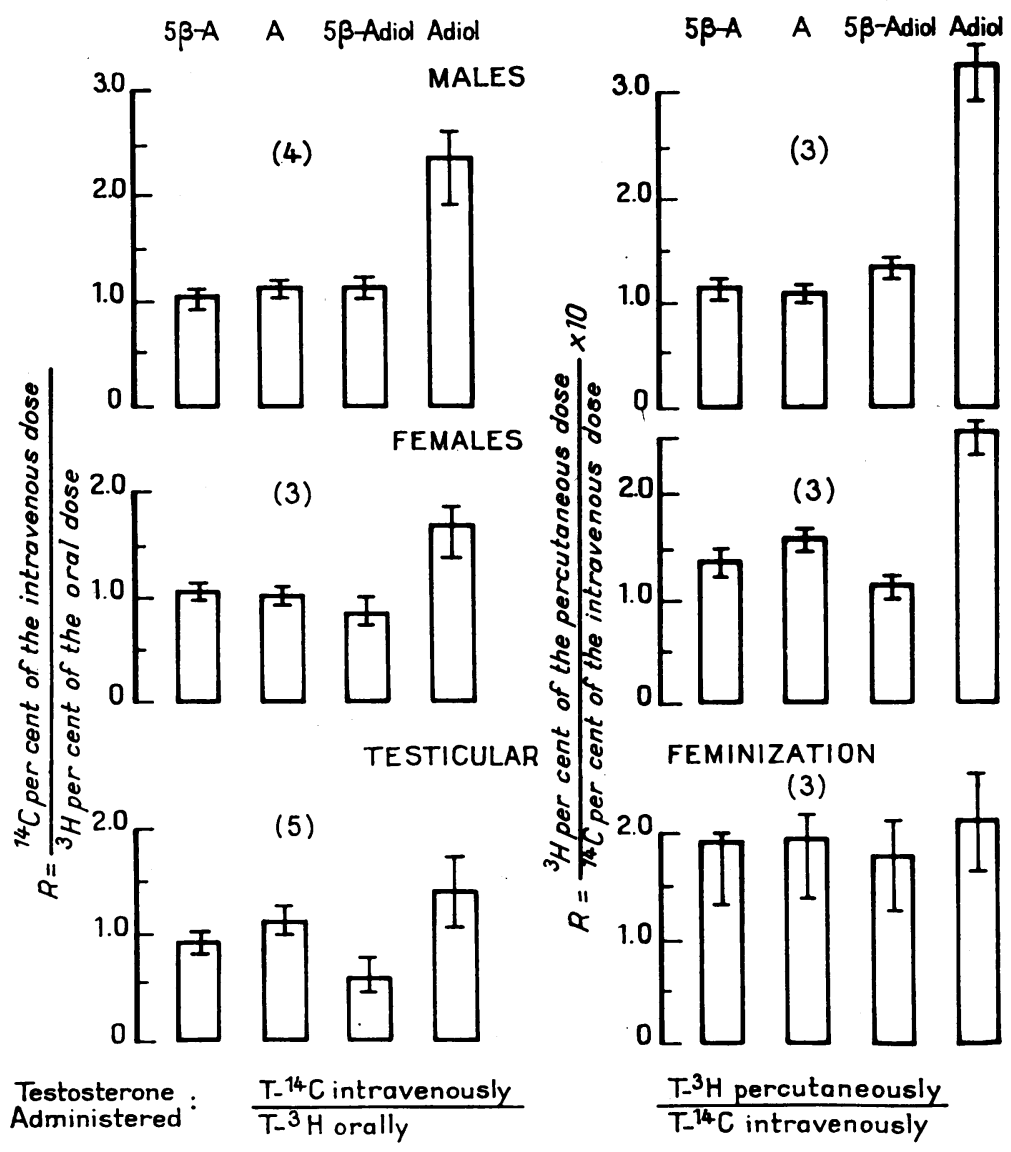

FIgURE 2 Proportion of an intravenous compared with an oral dose of,testosterone and proportion of a percutaneous compared with an intravenous dose of testosterone excreted as urinary 17-ketosteroids and androstanediols ( $R$ value, mean and range). In the case of experiments using the simultaneous administration of testosterone- ${ }^{3} \mathrm{H}$ orally and testosterone- ${ }^{14} \mathrm{C}$ intravenously, the

$\mathrm{R}$ value $=\frac{{ }^{3} \mathrm{H}::^{14} \mathrm{C} \text { ratio of the radioactive precursors }}{{ }^{3} \mathrm{H}:{ }^{14} \mathrm{C} \text { ratio in a purified sample of a metabolite }}$. As regards the simultaneous administration of testosterone- ${ }^{-3} \mathrm{H}$ percutaneously and testosterone-14 $\mathrm{C}$ intravenously, the $\mathrm{R}$ value $=$

$$
\frac{{ }^{14} \mathrm{C}:{ }^{8} \mathrm{H} \text { ratio of the radioactive precursors }}{{ }^{10} \mathrm{C}:{ }^{8} \mathrm{H} \text { ratio in a purified sample of a metabolite }} \times 10
$$

(see also Results). T, testosterone; $5 \beta$-A, $5 \beta$-androsterone; $\mathrm{A}$, androsterone; $5 \beta$-Adiol, $5 \beta$-androstanediol; Adiol, androstanediol. 
TABLE II

Recovery of Radioactivity in Urine after Simultaneous Administration of Testosterone- ${ }^{-3} \mathrm{H}$ by Percutaneous Route and Testosterone-14 C Intravenously

\begin{tabular}{|c|c|c|c|c|c|c|c|c|c|c|c|c|c|}
\hline \multirow[b]{2}{*}{ Subjects } & \multirow{2}{*}{$\begin{array}{c}\text { Ratio } \\
{ }^{2} \mathrm{H}:{ }^{14} \mathrm{C} \\
\text { of } \\
\text { precursors }\end{array}$} & \multicolumn{3}{|c|}{$5 \beta$-Androsterone } & \multicolumn{3}{|c|}{ Androsterone } & \multicolumn{3}{|c|}{ 5 $\beta$-Androstanediol } & \multicolumn{3}{|c|}{ Androstanediol } \\
\hline & & $\begin{array}{c}\text { cpm-s } \\
\times 10^{3}\end{array}$ & $\begin{array}{c}\mathrm{cpm}-14 \mathrm{C} \\
\times 10^{8}\end{array}$ & ${ }^{8} \mathrm{H}:{ }^{14} C^{*}$ & $\begin{array}{c}\mathrm{cpm}^{-3} \mathrm{H} \\
\times 10^{3}\end{array}$ & $\begin{array}{c}\mathrm{cpm}^{-14} \mathrm{C} \\
\times 10^{3}\end{array}$ & ${ }^{8} \mathrm{H}:{ }^{14} \mathrm{C} *$ & $\begin{array}{c}\text { cpm-s } \\
\times 10^{3}\end{array}$ & $\begin{array}{c}\mathrm{cpm}-18 \mathrm{C} \\
\times 10^{3}\end{array}$ & ${ }^{8} \mathrm{H}:{ }^{14} \mathrm{C} *$ & $\begin{array}{c}\mathrm{cpm}^{-3} \mathrm{H} \\
\times 10^{3}\end{array}$ & $\begin{array}{c}\mathrm{cpm}-14 \mathrm{C} \\
\times 10^{3}\end{array}$ & ${ }^{8} \mathrm{H}:{ }^{14} \mathrm{C} *$ \\
\hline \multicolumn{14}{|c|}{ Testicular feminization } \\
\hline N. G. & 6.8 & 105 & 114 & 0.92 & 154 & 160 & 0.96 & 10.7 & 12.5 & 0.86 & 5.6 & 4.9 & 1.15 \\
\hline J. Q. & 7.3 & 184 & 107 & 1.71 & 190 & 118 & 1.61 & 15.8 & 10.1 & 1.56 & 6.9 & 4.2 & 1.64 \\
\hline G. P. & 7.2 & 190 & 132 & 1.44 & 273 & 175 & 1.56 & 16.4 & 11.7 & 1.40 & 9.0 & 4.9 & 1.82 \\
\hline \multicolumn{14}{|c|}{ Normal males } \\
\hline A. H. & 8.1 & 140 & 143 & 0.98 & 114 & 135 & 0.85 & 25.4 & 21.7 & 1.17 & 26.6 & 10.0 & 2.66 \\
\hline P. M. & 8.8 & 121 & 120 & 1.01 & 102 & 106 & 0.96 & 27.4 & 25.9 & 1.05 & 36.4 & 14.2 & 2.56 \\
\hline F. D. & 8.6 & 85 & 83 & 1.03 & 188 & 186 & 1.01 & 21.7 & 20.2 & 1.07 & 34.7 & 11.7 & 2.96 \\
\hline \multicolumn{14}{|c|}{ Normal females } \\
\hline N. J. & 7.7 & 117 & 113 & 1.04 & 152 & 141 & 1.08 & 14.6 & 14.5 & 1.01 & 12.1 & 6.3 & 1.92 \\
\hline M. C. & 6.6 & 142 & 148 & 0.96 & 92 & 88 & 1.05 & 11.1 & 12.2 & 0.91 & 12.6 & 6.9 & 1.84 \\
\hline A. M. & 7.2 & 136 & 126 & 1.08 & 129 & 116 & 1.12 & 12.1 & 12.7 & 0.96 & 9.6 & 5.1 & 1.89 \\
\hline
\end{tabular}

* This ratio was obtained from a purified sample of the urinary metabolite.

$\mathrm{SE}$ and $0.35 \pm 0.06 \% \mathrm{SE}$. These values are not significantly different $(P<0.30)$. If one considers the proportion of intravenous compared to the oral dose of radioactive testosterone excreted as androstanediol, the $R$ values obtained were respectively 2.34 in males, 1.85 in females, and 1.45 in patients with feminizing testes. These mean $\mathrm{R}$ values are significantly different $(P<0.01)$ if one group of subjects is compared with another.

In a prepuberal patient (case M.B., Table I, Fig. 4), there was a greater proportion of androstanediol arising from the intravenously injected testosterone $(2.41 \%)$ than from the orally administered precursor $(0.77 \%)$. The $R$ value of androstanediol was therefore elevated (3.10). This pattern is quite similar to that observed in normal males and very different from that of patients studied after puberty. In addition when the prepuberal patient was treated with $1 \mathrm{mg}$ of diethylstilbestrol for only 10 days, there was a dramatic decrease in the contribution to androstanediol of testosterone injected in the peripheral circulation and not of testosterone orally administered. The relative contribution to androstanediol of the two doses of testosterone $(R=1.50)$ was then comparable to that of adult patients.

Simultaneous administration of testosterone- ${ }^{-3} \mathrm{H}$ by percutaneous route and of testosterone $-{ }^{14} \mathrm{C}$ by intravenous injection (Table $I I$ ). Only 4-6\% of radioactive testosterone percutaneously administered was recovered in the urine as 17 -ketosteroids and androstanediols. However, as long as the radioactive doses of testosterone were administered with an elevated ${ }^{3} \mathrm{H}:{ }^{14} \mathrm{C}$ ratio $(6.6-8.8)$, it was possible to determine with good precision the ${ }^{8} \mathrm{H}:{ }^{14} \mathrm{C}$ ratio in the recovered urinary metabolites. In normal males, females, and patients with feminizing testes, the ${ }^{8} \mathrm{H}:{ }^{14} \mathrm{C}$ ratios of androsterone, $5 \beta$-androsterone, and $5 \beta$ - androstanediol were very similar for all subjects. However in males, the ${ }^{8} \mathrm{H}:{ }^{14} \mathrm{C}$ ratios of androstanediol were 3 times the ${ }^{8} \mathrm{H}:{ }^{14} \mathrm{C}$ ratios of other metabolites. This difference was less important in females whereas in patients with feminizing testes the ${ }^{8} \mathrm{H}:{ }^{14} \mathrm{C}$ ratios of androstanediol did not differ from those of other metabolites. These data are emphasized by comparing for each group of subjects the proportion of percutaneous compared to intravenous dose of radioactive testosterone excreted as the same metabolite, i.e., $R$ value. This $R$ value was calculated for each metabolite by dividing the ${ }^{14} \mathrm{C}:{ }^{8} \mathrm{H}$ ratio of the injected compounds by the ${ }^{14} \mathrm{C}:{ }^{8} \mathrm{H}$ ratio in a purified sample of the metabolite (Fig. 2). The values obtained have been arbitrarily multiplied by 10 because the radioactivity recovered in urinary metabolites originating from percutaneous testosterone ${ }^{3}{ }^{\mathrm{H}} \mathrm{H}$ was only the 8 th to the 10 th part of radioactivity recovered in the metabolites arising from testosterone- ${ }^{14} \mathrm{C}$ intravenously injected. Then, it was possible to compare the mean $R$ values of the same metabolites arising from a combined dose of testosterone administered either percutaneously and intravenously or intravenously and orally.

Moreover, the contribution to androstanediol of each administered dose of testosterone was also appreciated by comparing the different $5 \alpha: 5 \beta$ ratios calculated from the radioactivity recovered in the urine as androstanediols (Fig. 3). In males the mean $5 \alpha: 5 \beta$ ratio of androstanediols arising from the percutaneous dose of testosterone is 3 and 6 times the corresponding ratio of diols originating respectively from the intravenous and the oral dose. In patients with feminizing testes the $5 \alpha: 5 \beta$ ratios of diols are very similar when testosterone is either intravenously or percutaneously administered. 


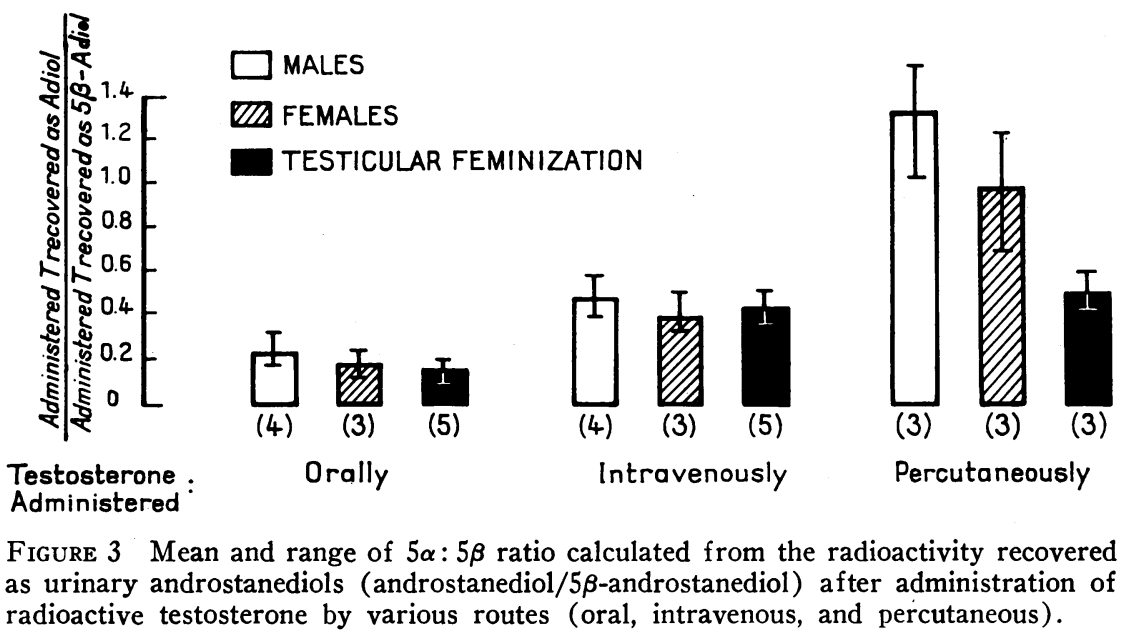

Longitudinal studies in a case of testicular feminization after castration (Fig. 4). After castration of the patient J.Q., there was a significant increase in the conversion rate to androstanediols (especially to the $5 \alpha$-compound) of radioactive testosterone intravenously injected. The yields of urinary diols were then similar to those of normal males. In addition, the treatment of this castrated patient with testosterone propionate did not modify the conversion rate of testosterone to diols, whereas his treatment with $5 \mathrm{mg}$ of diethylstilbestrol for 20 days was followed by a fall in urinary metabolites originating from the ring $\mathrm{A}$ reduction of testosterone.

Metabolism of $17 \alpha_{-}{ }^{5} H-4-{ }^{14} \mathrm{C}$-testosterone (Table III). In the normal male studied, the ${ }^{3} \mathrm{H}:{ }^{14} \mathrm{C}$ ratios of androstanediols and of testosterone glucuronide were very close and similar to the ${ }^{8} \mathrm{H}:{ }^{11} \mathrm{C}$ ratio of the injected testosterone. This was not the case in a patient with feminizing testes where the ${ }^{8} \mathrm{H}:{ }^{14} \mathrm{C}$ ratio of androstanediol differed significantly from the ${ }^{8} \mathrm{H}:{ }^{14} \mathrm{C}$ ratios of $5 \beta$-androstanediol and testosterone glucuronide. In the case of a male treated with $50 \mathrm{mg}$ of diethylstilbestrol for 20 days, a decrease in the ${ }^{3} \mathrm{H}:{ }^{14} \mathrm{C}$ ratio of androstanediol was only observed. These results mean that in these two subjects and contrarily to what is observed in the untreated normal male, more than $50 \%$ of androstanediol $-{ }^{14} \mathrm{C}$ recovered in urine after injection of $17 \alpha-{ }^{8} \mathrm{H}-{ }^{14} \mathrm{C}-$ testosterone are formed via a "17-ketonic pathway," such as, testosterone $\rightarrow$ androstenedione $\rightarrow$ androstanedione $\rightarrow$ androsterone $\rightarrow$ androstanediol, and not from the $5 \alpha$-reduction of testosterone (see Fig. 1).

Metabolism of androstanolone and testosterone ( $\mathrm{Ta}$ ble $I V)$. With respect to the normal male, androstanolone- ${ }^{8} \mathrm{H}$ and testosterone $-{ }^{14} \mathrm{C}$ contribute to urinary androstanediol and androstanolone glucuronides in the

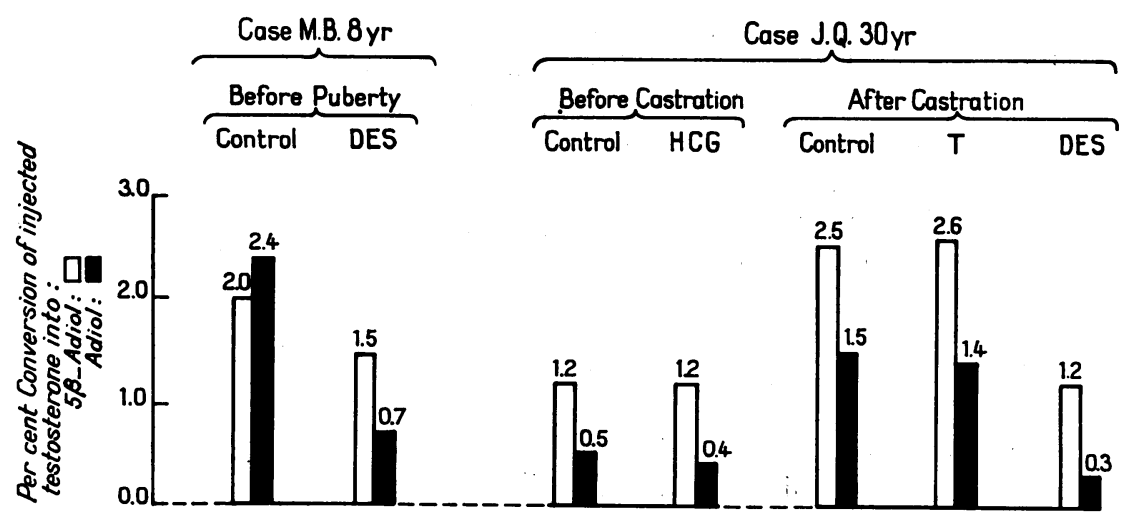

Figure 4 A longitudinal study on testosterone metabolism in two cases of testicular feminization syndrome. M. B., prepuberal case and J. Q., postpubertal case. The results are expressed as per cent conversion of radioactive testosterone intravenously injected to urinary androstanediol and $5 \beta$-androstanediol. $H C G=$ values after treatment with 1500 UI HCG for 10 days. $T=$ values after injection of testosterone propionate $(25 \mathrm{mg}$ daily $\times 30$ days $) . \mathrm{DES}=$ values after treatment with diethylstilbestrol ( $1 \mathrm{mg}$ daily $\times 10$ days in the case M. B. and $5 \mathrm{mg}$ daily $\times 20$ days in the case J. Q.). 
TABLE III

Recovery of Radioactivity in Urine after Intravenous Injection of $17 \alpha^{-3} \mathrm{H}-4-{ }^{14} \mathrm{C}$-testosterone

$\left(T-17 \alpha-{ }^{3} H\right.$ and $\left.T-14 C\right)$

\begin{tabular}{|c|c|c|c|c|c|c|c|c|c|c|}
\hline \multirow[b]{3}{*}{ Subjects } & \multirow{3}{*}{$\begin{array}{l}\text { Ratio } \\
{ }^{2} \mathrm{H}:{ }^{14} \mathrm{C} \\
\text { of pre- } \\
\text { cursors }\end{array}$} & \multicolumn{3}{|c|}{$5 \beta$-Androstanediol } & \multicolumn{3}{|c|}{ Androstanediol } & \multicolumn{3}{|c|}{ Testosterone* } \\
\hline & & \multicolumn{2}{|c|}{$\begin{array}{l}\text { Per cent con- } \\
\text { version }\end{array}$} & \multirow[b]{2}{*}{${ }^{8} \mathrm{H}:{ }^{14} \mathrm{C} \ddagger$} & \multicolumn{2}{|c|}{$\begin{array}{l}\text { Per cent con- } \\
\text { version }\end{array}$} & \multirow[b]{2}{*}{${ }^{2} \mathrm{H}:{ }^{14} \mathrm{C} \ddagger$} & \multicolumn{2}{|c|}{$\begin{array}{l}\text { Per cent con- } \\
\text { version }\end{array}$} & \multirow[b]{2}{*}{${ }^{3} \mathrm{H}: 14 \mathrm{C} \ddagger$} \\
\hline & & $T-17 \alpha-{ }^{-2} H$ & $T-14 \mathrm{C}$ & & $\mathrm{T}-17 \alpha-2 \mathrm{H}$ & $T-14 \mathrm{C}$ & & $T-17 \alpha-2 \mathrm{H}$ & $\mathrm{T}-1+\mathrm{C}$ & \\
\hline \multicolumn{11}{|l|}{ Normal male (J. H.) } \\
\hline Control & 1.79 & 3.50 & 3.51 & 1.76 & 1.62 & 1.71 & 1.70 & 0.91 & 0.91 & 1.80 \\
\hline DES\& & 1.68 & 3.24 & 3.21 & 1.64 & 0.14 & 0.40 & 0.59 & 0.50 & 0.51 & 1.65 \\
\hline \multicolumn{11}{|l|}{ Testicular femi- } \\
\hline nization (G. P.) & 2.82 & 0.86 & 1.32 & 1.84 & 0.16 & 0.31 & 1.40 & 0.50 & 0.52 & 2.79 \\
\hline
\end{tabular}

* Testosterone isolated in the glucuronide fraction of the urine.

$\ddagger$ This ratio was obtained from a purified sample of the urinary metabolite.

\& After treatment with $\mathbf{5 0} \mathrm{mg}$ of diethylstilbestrol daily for $\mathbf{2 0}$ days.

same proportions since the ${ }^{8} \mathrm{H}:{ }^{14} \mathrm{C}$ ratios of these metabolites are very close. In the patient with feminizing testes as in the male treated with diethylstilbestrol, practically no androstanolone glucuronide was recovered in the urine from the injected radioactive testosterone, and the ${ }^{8} \mathrm{H}:{ }^{14} \mathrm{C}$ ratios of urinary androstanediol and androstanolone glucuronides were very different. These results confirm that in the latter subjects androstanolone is not an important metabolic intermediate between testosterone and androstanediol.

Testosterone binding levels in serum (Fig. 5). The relative binding affinity of serum protein for testosterone was significantly higher in patients with feminizing testes than in normal males $(P<0.05)$ and very similar to that of normal females. The mean values (in liters/gram of serum protein) were, respectively, 1.56 $\pm 0.59 \mathrm{sE}$ for testicular feminization syndrome cases ( $n=6$ determinations), $0.90 \pm 0.21$ sE for males $(n=5$ determinations), and $1.43 \pm 0.30$ se for females $(n=8$ determinations).

After administration of diethylstilbestrol ( $5 \mathrm{mg}$ daily for 20 days), there was a very striking increase in testosterone binding levels in the case of patients with feminizing testes but not in the case of normal males. The values obtained in patients with feminizing testes were then similar to those observed in females during the first trimester of pregnancy.

\section{DISCUSSION}

As far as experiments using the intravenous injection of radioactive testosterone are concerned, it seems likely that in the adult patients with untreated feminizing testes circulating testosterone is largely oxidized to androstenedione and then reduced to androsterone, isoandrosterone, and $5 \beta$-androsterone (4-7). Unlike normal males, these patients show ring $A$ reduction of testos-

TABLE IV

Recovery of Radioactivity in Urine after Intravenous Injection of Androstanolone- ${ }^{3} \mathrm{H}$ and Testosterone- ${ }^{14} \mathrm{C}$

\begin{tabular}{|c|c|c|c|c|c|c|c|}
\hline \multirow[b]{2}{*}{ Subjects } & \multirow{2}{*}{$\begin{array}{l}\text { Ratio } \\
{ }^{2} \mathrm{H}:{ }^{14} \mathrm{C} \\
\text { of pre- } \\
\text { cursors }\end{array}$} & \multicolumn{3}{|c|}{ Androstanediol } & \multicolumn{3}{|c|}{ Androstanolone* } \\
\hline & & cpm-sH & $\mathrm{cpm}-\mathrm{HAC}$ & ${ }^{8} \mathrm{H}:{ }^{14} \mathrm{C}$ & $\mathrm{cpm}-\mathrm{SH}_{\mathrm{H}}$ & $\mathrm{cpm}^{-14} \mathrm{C}$ & ${ }^{8 \mathrm{H}}:{ }^{14} \mathrm{C}$ \\
\hline \multicolumn{8}{|c|}{ Normal male (P. M.) } \\
\hline Control & 3.1 & 229,032 & 20,211 & 11.3 & 9380 & 700 & 13.4 \\
\hline DES $\ddagger$ & 3.4 & 101,109 & 3,348 & 30.2 & 2250 & 30 & 75 \\
\hline $\begin{array}{l}\text { Testicular femi- } \\
\text { nization (F. L.) }\end{array}$ & 3.4 & 92,400 & 7,000 & 13.2 & 1050 & 15 & 70 \\
\hline
\end{tabular}

* Androstanolone was recovered as a glucuronide in the ketonic fraction of the urine. The values expressed in the table are those obtained after two crystallizations to constant specific activity. $\ddagger$ After treatment with $50 \mathrm{mg}$ diethylstilbestrol daily for 20 days. 
terone to androstanediols only to a small extent. Most of the androstanediol recovered in the urine of these patients is formed via a "17-ketonic intermediate" such as androsterone. The results obtained from experiments using a combined injection of testosterone $-{ }^{14} \mathrm{C}$ and of either testosterone- $17 \alpha-{ }^{8} \mathrm{H}$ or androstanolone- ${ }^{3} \mathrm{H}$ emphasized this possibility. However, these experiments cannot give any information on the respective role of liver and target tissues in the metabolic abnormalities observed in patients with feminizing testes. Therefore, it was interesting to study the fate of radioactive testosterone according to its mode of administration (oral, intravenous, or percutaneous). In the case of oral administration, the steroid first enters the liver by way of the portal vein. When testosterone is intravenously injected into the peripheral circulation, it perfuses the target tissues before entering the liver by the hepatic artery. In the case of percutaneous administration, testosterone must pass through the skin and eventually through the muscle before reaching the peripheral circulation. With such experimental models, it is possible to compare the metabolism of testosterone circulating in the peripheral blood with that of the same precursor directly brought into the liver or into the target tissues.

In normal males whatever its mode of administration, radioactive testosterone contributes identically to its $5 \beta$ hydrogenated metabolites. Such a result is compatible with data indicating that in normal males $5 \beta$-reduction of testosterone does not occur to any significant extent in extrahepatic tissues $(9,18,19)$.

In contrast the yield of androstanediol originating from testosterone injected in the peripheral circulation

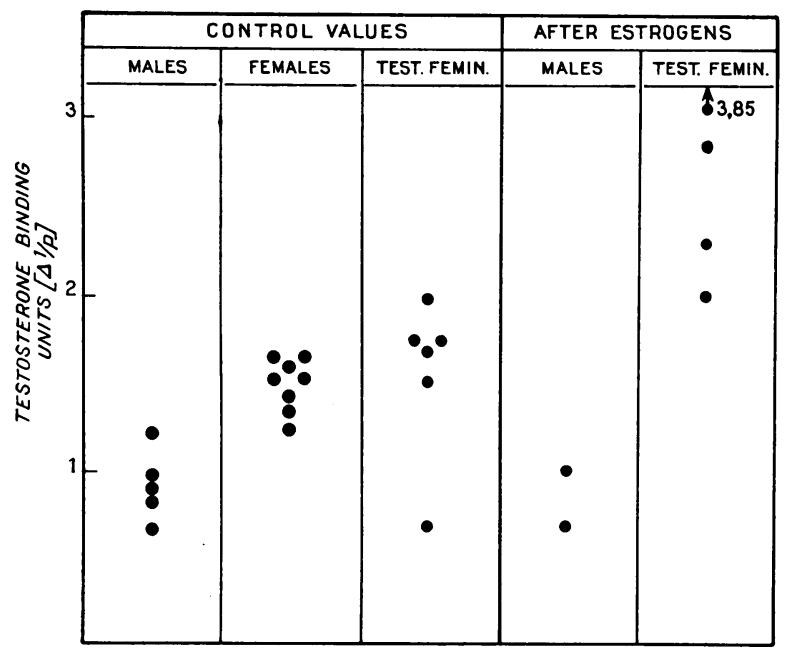

FIgURE 5 Testosterone binding levels in the serum of normal subjects and patients with the syndrome of testicular feminization. Control values and values observed after treatment with $5 \mathrm{mg}$ diethylstilbestrol daily for 20 days. is 2 times higher than that originating from testosterone which enters the liver directly by the portal vein, whereas the yield of androstanediol arising from testosterone percutaneously applied is 2.5 times higher than that arising from testosterone injected in the peripheral circulation. These results are in agreement with in vitro data suggesting that a characteristic of cutaneous testosterone metabolism is the stereospecific reduction of the ring $A$ leading to the formation of $5 \alpha$-androstane steroids $(18,19)$. The actual importance of testosterone metabolism by an organ as large as the skin is difficult to establish. However, from our in vivo results it may be postulated that at least $50 \%$ of androstanediol recovered in the urine of males arise from the $5 \alpha$-reduction of testosterone outside the liver. Contrary to what is observed in males, the extrahepatic $5 \alpha$-reduction of testosterone seems to be negligible in patients with feminizing testes since identical yields of urinary androstanediol result whatever the mode of administration of radioactive testosterone. These in vivo data are in agreement with those obtained by Wilson and Walker (20) and by Northcutt, Island, and Liddle (21) from in vitro experiments. From these reports, there could be a lack of testosterone $5 \alpha$-reduction in the skin of patients with testicular feminization syndrome. Furthermore in the light of our results, the hepatic $5 \beta$-reduction of testosterone seems to be hampered if one considers the low yield of $5 \beta$-androstanediol originating from testosterone intravenously injected to these patients.

Estrogens seem to be importantly involved in the metabolic abnormalities observed in patients with testicular feminization syndrome. In subjects without estrogen production, such as prepuberal or castrated patients, the yield of androstanediol arising from testosterone is comparable to that of normal males. In males it is possible to inhibit with diethylstilbestrol the reduction of testosterone to androstanolone and androstanediol (6). In other words, testosterone is metabolized in the same way in males treated with diethylstilbestrol as it is in patients without estrogen deprivation. However, the inhibitory effect of estrogen upon testosterone $5 \alpha$-reduction may be obtained in castrated and prepuberal patients with a dose which is 10 times smaller than in normal males. One can therefore wonder if the decrease in testosterone $5 \alpha$-reduction observed in patients with feminizing testes reflects an enzymatic impairment or is only the result of the abnormal sensitivity of a specific enzyme to estrogens originating either directly from testes or indirectly from the peripheral conversion of testosterone and androstenedione (22, 23). Estrogen may act by ( $a$ ) inhibition of the enzyme allowing in target cells the hydrogenation of testosterone to androstanolone as the nuclear enzyme described by Bruchovsky and Wilson (12) and Anderson and Liao (13) 
or (b) increase of specific plasma protein binding testosterone $(24,25)$ so that almost no unbound testosterone may be available in target cells for $5 \alpha$-reduction. This last hypothesis is sustained by the high binding levels for testosterone observed in the plasma of patients, and furthermore, seems very consistent regarding the hepatic $5 \beta$-reduction of testosterone which is very low when the steroid is injected intravenously but is normal when testosterone is orally administered. In the case of oral administration, testosterone probably enters the liver before being bound to a specific protein (26) contrarily to what is observed when the steroid is injected in the peripheral circulation.

Although data concerning estrogen production in patients with feminizing testes do not permit a firm conclusion $(1,27,28)$, it seems likely that this production does not exceed that of normal males. Thus, there seems to exist in subjects with testicular feminization syndrome an abnormal synthesis of plasma-binding protein under the effect of circulating estrogens. This hypothesis is supported by the fact that with the same low dose of diethylstilbestrol plasma-binding levels for testosterone were not modified in males but did increase dramatically in patients with feminizing testes. That castrated patients do not respond to testosterone does not exclude such an hypothesis. In males as in patients with feminizing testes, the main part of circulating estrogens originates from peripheral conversion of testosterone $(22,23)$. Therefore, treatment with testosterone of castrated patients may maintain an elevated binding level in plasma.

However, it has not actually been proven that the synthesis of specific protein(s) binding testosterone in plasma is altered in testicular feminization syndrome. Thus, further investigation must be undertaken before it can be said if the metabolic abnormalities observed in patients with this genetic disease are due to the absence of specific enzyme(s), or to an elevated binding of testosterone to proteins which preverits the penetration of this androgen in target cells, or to both. Furthermore, it has not definitively been proven that the lack of masculinization observed in patients with feminizing testes depends upon the absence of biotransformation of testosterone to androstanolone in target tissues.

\section{ACKNOWLEDGMENTS}

The technical assistance of Mrs. N. Baudot is gratefully acknowledged. We are indebted to Professors Laplane, Bricaire, and Musset, and Doctors Henrion, Lasfargues, Luton Roy, and Sebaoun for allowing us to study their patients. Dr. J. A. Guichard and Miss D. Ravelet are acknowledged for their help in writing this manuscript.

This work was supported in part by a grant of the Institut National de la Santé et de la Recherche Médicale (INSERM).

\section{REFERENCES}

1. Simmer, H. H., R. J. Pion, and W. J. Dignam. 1965. Testicular Feminization. Charles C Thomas, Pub. Springfield, IIl.

2. French, F. S., J. J. Van Wyk, B. Baggett, W. E. Easterling, L. M. Talbert, F. R. Johnston, E. Forchielli, and A. C. Dey. 1966. Further evidence of a target organ defect in the syndrome of testicular feminization. J. Clin. Endocrinol. Metab. 26: 493.

3. Rivarola, M. A., J. M. Saez, W. J. Meyer, F. M. Kenny, and C. J. Migeon. 1967. Studies of androgens in the syndrome of male pseudohermaphroditism with testicular feminization. J. Clin. Endocrinol. Metab. 27 : 371.

4. Mauvais-Jarvis, P. 1966. Etude du métabolisme 17 $\beta$-hydroxylé de la testosterone en fonction de la différentiation sexuelle humaine. C. R. Acad. Sci. Paris. 262: 2753.

5. Mauvais-Jarvis, P., H. H. Floch, and J. P. Bercovici 1968. Studies on testosterone metabolism in human subjects with normal and pathological sexual differentiation. J. Clin. Endocrinol. Metab. 28: 460.

6. Mauvais-Jarvis, P., J. P. Bercovici, and H. H. Floch. 1969. Influence des hormones sexuelles sur le métabolisme des androgènes. Rev. Fr. Etud. Clin. Biol. 14: 159.

7. Mauvais-Jarvis, P., and J. P. Bercovici. 1968. Abnormalities of testosterone metabolism in the syndrome of testicular feminization. In Research on Steroids. Proceedings of the Third Meeting of the International Study Group for Steroid Hormones. C. Cassano, editor. North Holland Publishing Co., Amsterdam. Vol. III. 93.

8. Farnsworth, W. E., and J. R. Brown. 1963. Testosterone metabolism in the prostate. Nat. Cancer Inst. Monogr. 12: 323.

9. Chamberlain, J., N. Jagarinec, and P. Ofner. 1966. Catabolism of $\left[4-{ }^{14} \mathrm{C}\right]$ testosterone by subcellular fractions of human prostate. Biochem. J. 99: 610.

10. Dorfman, R. I., and A. S. Dorfman. 1963. Assay of androgens administered by inunction to the chick's comb. Acta Endocrinol. 42 (Suppl. 74).

11. Hilgar, A. G., and D. J. Hummel. 1964. In Androgenic and Myogenic Endocrine. Bioassays Data, Bethesda, Md. 1: 46.

12. Bruchovsky, N., and J. D. Wilson. 1968. The conversion of testosterone to $5 \alpha$-androstan-17 $\beta$-ol-3 one by rat prostate in vivo and in vitro. J. Biol. Chem. 243: 2012.

13. Anderson, K. M., and S. Liao. 1968. Selective retention of dihydrotestosterone by prostatic nuclei. Nature (London). 219: 277.

14. Mauvais-Jarvis, P., J. P. Bercovici, and F. Gauthier. 1969. In vivo studies on testosterone metabolism by skin of normal males and patients with the syndrome of testicular feminization. J. Clin. Endocrinol. Metab. 29: 417.

15. Baulieu, E. E., and P. Mauvais-Jarvis. 1964. Studies on testosterone metabolism. I. Conversion of testosterone$17 \alpha-{ }^{3} \mathrm{H}$ to $5 \alpha$ - and $5 \beta$-androstane-3 $\alpha, 17 \beta$-diol- $17 \alpha-{ }^{8} \mathrm{H}:$ a new "17 $\beta$-hydroxyl pathway."J. Biol. Chem. 239: 1569.

16. Mauvais-Jarvis, P., H. Floch, I. Jung, P. Robel, and E. E. Baulieu. 1968. Studies on testosterone metabolism. VI. Precursors of urinary androstanediols. Steroids. 11: 207.

17. Pearlman, W. H., and O. Crepy. 1967. Steroid-protein interaction with particular reference to testosterone binding by human serum. J. Biol. Chem. 242: 182. 
18. Rongone, E. L. 1966. Testosterone metabolism by human male mammary skin. Steroids. 7: 489.

19. Gomez, E. E., and S. L. Hsia. 1968. In vitro metabolism of Testosterone-4- ${ }^{11} \mathrm{C}$ and $\Delta$-4-Androstene-3,17-dione-4${ }^{14} \mathrm{C}$ in human skin. Biochemistry: $7: 24$.

20. Wilson, J. D., and J. D. Walker. 1969. The conversion of testosterone to $5 \alpha$-androstan-17 $\beta$-ol-3-one (dihydrotestosterone) by skin slices of man. J. Clin. Invest. 48: 371

21. Northcutt, R. C., D. P. Island, and G. W. Liddle. 1969. An explanation for the target organ unresponsiveness to testosterone in testicular feminization syndrome. J. Clin. Endocrinol. Metab. 29: 422.

22. Longcope, C., D. S. Layne, and J. F. Tait. 1968. Metabolic clearance rates and interconversions of estrone and $17 \beta$-estradiol in normal males and females. J. Clin. Invest. $47: 93$.

23. Mac Donald, P. C., R. P. Rombaut, and P. K. Siiteri 1967. Plasma precursors of estrogen. I. Extent of conversion of plasma $\Delta 4$-androstenedione to estrone in normal males and nonpregnant normal, castrate and adrenalectomized females. J. Clin. Endocrinol. Metab. 27: 1103 .

24. Pearlman, W. H., O. Crepy, and M. Murphy. 1967. Testosterone-binding levels in the serum of women during the normal menstrual cycle, pregnancy, and the post-partum period. J. Clin. Endocrinol. Metab. 27: 1012.

25. Rosner, W. and S. M. Deakins. 1968. Testosteronebinding globulins in human plasma: studies on sex distribution and specificity. J. Clin. Invest. 47: 2109.

26. Yates, F. E. 1967. The liver and the adrenal cortex. Gastroenterology. 53: 477.

27. Southren, A. L., S. Tochimoto, N. C. Carmody, and K. Isurugi. 1965. Plasma production rates of testosterone in normal adult men and women and in patients with the syndrome of feminizing testes. J. Clin. Endocrinol. Metab. 25: 1441 .

28. Hutchinson, H. T., R. Rombaut, P. Mac Donald, and P. K. Siiteri. 1969. Metabolism of androgens in testicular feminization. 51st Meeting of the Endocrine Society. Abstr. no. 250 